\title{
Kadına Yönelik Aile İçi Şiddet ve Kadının İşgücüne Katılımına ilişskin Mikroekonometrik Analiz: Türkiye
}

\section{Microeconometric Analysis of Domestic Violence Against Women and Women's Labour Force Participation: Evidence from Turkey}

\section{Dr.Öğr. Üyesi Evren ipek ${ }^{1}$ - Dr. Öğr. Üyesi Özlem Ayvaz Kızılgöl²}

Başvuru Tarihi: 26.05.2018

Kabul Tarihi: 28.05.2019

\section{Öz}

Kadına yönelik aile içi şiddet, boyutu ve türleri değişmekle beraber tüm dünyada kadınların yaşadiğı ortak ve önemli bir toplumsal sorundur. Kadına yönelik aile içi şiddet kadınları sadece fiziksel ve psikolojik olarak etkilememekte ayn zamanda hukuki, sosyal, siyasal ve ekonomik statülerinin gelişmesini de engellemektedir. Bu çalışmada, kadına yönelik aile içi şiddeti etkileyen faktörler belirlenmeye çalışılmış ve kadının işgücüne katılımının aile içi şiddet üzerindeki etkisi değerlendirilmiştir. Veriler, 2008 ve 2014 yıllarında Türkiye İstatistik Kurumu tarafindan yapılan "Türkiye’de Kadına Yönelik Aile İçi Şiddet Araştırması” anketlerinden elde edilmiştir. Analiz iki durumlu logit model ile gerçekleştirilmiştir. Analiz sonuçlarına göre kadının yaşı arttıkça kadına yönelik şiddetin arttığı tespit edilmiştir. Kadının ve eşinin eğitim düzeyi arttıkça aile içi şiddetin azaldığı görülmüştür. Kadının çalışması yani işgücüne katılması şiddet görmesini engelleyen bir faktör değildir. Çalışan kadınların çalışmayan kadınlara göre fiziksel ya da cinsel şiddet yaşama olasılı̆̆ daha fazladır. Eşlerin alkol kullanması, kumar oynaması ve uyuşturucu kullanması durumunda aile içi şiddetin arttığı belirlenmiştir. Marmara Bölgesine göre en fazla aile içi şiddetin yaşandiğı bölge 2008 yılında Doğu Anadolu Bölgesi, 2014 yılında İç Anadolu Bölgesi olarak tespit edilmiştir.

Anahtar Kelimeler: Kadına Şiddet, İşgücüne Katılım, Türkiye, Logit Model

\begin{abstract}
Domestic violence against women is a common and important social problem for women in all over the world since the size and type of it varies among countries. Domestic violence against women does not only affect women physically and psychologically, but at the same time impedes the development of legal, social, political and economic status of them. This study aims to analyze the factors influencing the domestic violence against women and evaluates the impact of labor force participation of women on domestic violence. The data is obtained from the Surveys on Domestic Violence against Women in Turkey that are conducted by Turkish Statistical Institute
\end{abstract}

\footnotetext{
${ }^{1}$ Bandırma Onyedi Eylül Üniversitesi İİBF, eipek@bandirma.edu.tr, ORCID: 0000-0003-4855-6545

${ }^{2}$ Bandırma Onyedi Eylül Üniversitesi İIBF, okizilgol@bandirma.edu.tr, ORCID: 0000-0001-9996-7892
} 
in 2008 and 2014. The analysis is performed with binomial logit model. The empirical results indicate that as the age of women increases, domestic violence against women increases. It is detected that as the education level of women and her spouse increases, domestic violence decreases. According to the results, employment of women, in other words the labor force participation of women, does not a factor that prevent women from domestic violence. Working women are more likely to experience physical or sexual violence than non-working women. The results indicate that domestic violence increases in case spouses use alcohol, use drugs or gamble. When compared with Marmara Region, the region where the domestic violence is experienced most is determined as Eastern Anatolia Region in 2008 and Central Anatolia Region in 2014.

Keywords: Violence Against Women, Labour Force Participation, Turkey, Logit Model.

\section{Giriş}

Şiddet, Dünya Sağlık Örgütü’nün (WHO) 2002 yılında yayınladığ genel olarak "fiziksel zorlama ya da gücün niyet dahilinde bir şahsa veya gruba yönelik olarak uygulanışı" şeklinde tanımlanmıştır. Şiddet fiziksel, cinsel, duygusal (psikolojik) ve ekonomik gibi çeşitli şekillerde gerçekleşebilir. Fiziksel şiddet; kişiye fiziksel olarak zarar vermeyi amaçlayan vurma, tokat atma, itme, saçını çekme, kol bükme, tekme atma, boğazını sıkma, herhangi bir aletle yaralama, sağlıksız koşullarda yaşamaya zorlama vb. hareketleri içermekte ve öldürmeye kadar uzanan çok geniş bir kapsama alanı bulunmaktadır. Cinsel şiddet; taciz, tecavüz, ensest, zorla evlendirme vb. konuları kapsamaktadır. Duygusal (psikolojik) şiddet; aşağılama, hakaret etme, bağırma, küfretme, dalga geçme, karar verme hakkına engel olma, aileyle ve arkadaşlarla konuşma hakkını elinden alma, ekonomik veya sosyo-kültürel üstünlük belirtme vs. gibi davranışları içermektedir. Yaygın olarak görülen bir diğer aile içi duygusal şiddet biçimi de özgürlükten yoksun bırakmadır. Kişiyi evde bir odaya kilitlemek, dışarıya yalnız çıkmasına izin vermemek buna örnektir. Ekonomik şiddet ise zorla çalıştırma, çalışmasına engel olma, kadının çalışmasını ve konumunu küçümseme, kadının gelirini kullanmasını önleme, kişisel malvarlığının izinsiz kullanımı vb. gibi konuları içermektedir (Karal ve Aydemir, 2012, s. 22-23; Ararat vd., 2014, s. 22, Adaçay ve Güney, 2012, s. 314).

Kadına yönelik şiddetin kadın hakları ihlali olduğuna vurgu yapan Dünya Sağlı Örgütü’nün raporlarına göre dünyadaki kadınların yaklaşık 3’te biri (\%30) yaşamları boyunca yakın ilişkide bulundukları erkekler tarafından uygulanan fiziksel ve/veya cinsel şiddete maruz kalmışlardır. Bununla birlikte kadın cinayetlerinin \%38'inin de kadınların yakın ilişkide bulundukları erkek partnerleri tarafından gerçekleştirildiği raporlanmıştır. Kadının yakın ilişkide olduğu erkek partnerinden hayatı boyunca uğradığı fiziksel şiddetin yaygınlığına ilişkin UNSTATS verileri incelendiğinde bu oranın Uganda'da \%42.7; Kenya'da \%37; Hindistan'da \%35.1; Misır'da \%33.2 olduğu ve Türkiye'nin de \%36 gibi bir değerle şiddet yaygınlığının yüksek olduğu bu ülkeler arasında yer aldığı görülmektedir. Kadına yönelik fiziksel şiddet yaygınlığının Avrupa ülkelerinde görece daha düşük olup Fransa'da \%25, Almanya'da \%20; İtalya'da \%17; 
Hollanda'da \%22; İspanya'da \%12; Yunanistan'da \%18; Bulgaristan'da \%22 olduğu tespit edilmektedir. ${ }^{3}$

Ülkemizde 1980'lerde kadın hareketleriyle başlayan 1990'larda kurumsallaşan ve 2000'li yıllardan sonra sorunun çözümü için yapılan çalışmalar hız kazanmış olmasına rağmen halen sorunun çözümüyle ilgili eksiklikler bulunmakta, kadına şiddet olayları gittikçe artmaktadır (Oktay, 2015, s. 111). Kadın Cinayetlerini Durduracağız Platformu'nun 2017 yılı veri raporuna göre, Türkiye'de 2008-2017 yılları arasında öldürülen kadın sayıları ciddi boyutlardadır ve giderek artmıştır. 2008 yılında 80, 2009 yılında 109, 2010 yılında 180, 2011 yılında 121, 2012 yılında 210, 2013 yılında 237, 2014 yılında 294, 2015 yılında 303, 2016 yılında 328 ve 2017 yılında 409 kadın erkekler tarafından öldürülmüsstür. Kadınların \%22'si kocası, \%13'ü tanıdığı birisi veya akrabası, \%9'u erkek arkadaşı, \%5’i boşandığı erkek, \%4’ü babası, \%4'ü oğlu, \%3'ü ayrıldığı erkek arkadaşı, \%2'si ağabeyi ve \%1'i üvey oğlu tarafından öldürülmüştür (Kadın Cinayetlerini Durduracağız Platformu).

Türkiye'de kadına yönelik şiddeti konu alan ayrıntılı bilgi ve veri sağlayan araştırma sayısı oldukça azdır. Hem aile mahremiyeti olarak düşünüldüğü için, hem de insanların kendilerine şiddet uygulandığını itiraf etmeleri son derece güç olduğu için kadınların yaşadıkları şiddete ilişkin gerçek bilgilerin elde edilmesi mümkün görünmemektedir (Oktay, 2015, s. 85). Ülkemizde bu alanda yapılan sınırlı yerel araştırmalar yanında son yıllarda az sayıda ulusal araştırma da gerçekleştirilmiştir. Literatürde bu konudaki eksikliği dikkate alan bu çalışmada, Türkiye'de 2008 ve 2014 yıllarında kadına karşı aile içi şiddeti belirleyen unsurlar ortaya konmaya çalışılmış, her iki yıl için karşılıklı değerlendirmeler yapılmış ve ayrıca kadının işgücüne katılımının şiddet üzerindeki etkisi ölçülmeye çalışılmıştır. Türkiye'de bu konuda az sayıda olan ulusal çaptaki çalışmalarda tek bir yıl için analizler gerçekleştirilmiş, yıllar bazında şiddetin boyutu değerlendirilmemiştir. Bu sayılan nedenler, çalışmayı diğer çalışmalardan farklı kılmaktadır.

Çalışmanın diğer bölümleri şu şekilde ele alınmıştır: ikinci bölümde kadına karşı şiddeti belirleyen unsurları ele alan deneye dayalı çalışmalar incelenecek, üçüncü bölümde kadının işgücüne katılımının kadına yönelik aile içi şiddet üzerindeki etkisi değerlendirilecek, dördüncü bölümde deneye dayalı analizde kullanılan veri seti ve değişkenler tanıtılacak ve analiz sonuçları yorumlanacak, beşinci bölümde ise sonuç ve önerilere yer verilecektir.

\section{Literatür Taraması}

Kadına yönelik aile içi şiddeti konu alan çeşitli deneye dayalı çalışmalar mevcuttur. Bu çalışmalardan bazıları şunlardır: Mayda ve Akkuş (2004), evli kadınlara karşı aile içi şiddetle ilişkili faktörleri, şiddete karşı kadının davranışını ve şiddetle ilgili olarak sağlık personelinin

\footnotetext{
${ }^{3}$ BM İstatistik Bölümü (UNSTATS) tarafından yayınlanan “Dünya'da Kadın 2015: Eğilimler ve İstatistikler” kitabının altıncı bölümünde yer alan "Kadına Yönelik Şiddet” ile ilgili veriler çerçevesinde; çeşitli ülkelerde kadına yönelik şiddetin mevcut durumu çalışmanın Ek kısmında Tablo 1'de gösterilmektedir.
} 
soruları doğrultusunda kadının davranışını açıklamaya çalışmışlardır. Düzce ilinde 116 evli Türk kadınıyla yatay kesite dayanan bir araştırma yapmışlardır. Aile içi fiziksel şiddetin yaygınlığı \%41.4, duygusal şiddetin yaygınlığ $\% 25.9$, cinsel şiddetin yaygınlığı \%8.6 bulunmuştur ve kadınların eşi tarafından kontrol edilen herhangi bir davranışının oranı \%77.6'dır. Yaşamlarının herhangi bir döneminde fiziksel şiddeti yaşayan kadınların oranı \%50.9'dur. Fiziksel şiddet oranı hem kadınların hem eşlerinin düşük eğitim düzeyiyle ve onların doğum yeriyle ilişkili bulunmuştur. "Kocalar eşlerini dövemez" düşüncesinin eğitimli kadınlar arasında daha yaygın olduğu görülmüştür. Kadınların \%82'si sağlık personeli tarafından aile içi şiddet hakkında sorulan soruları cevaplamaya gönüllü olmuştur. Herhangi bir kadının veya eşinin kültürel geçmişi ve eğitimi, evde şiddet davranışının benimsenmesi ve tahammül edilmesi olasılığını etkilemektedir. Şiddetin sorgulanmasının, kadınların sağlık hizmetlerinde bir rutin olması gerektiği ve çoğu kadına uygulanması gerektiği önerilmiştir.

Ergin vd. (2005) Türkiye'nin sosyoekonomik olarak gelişmiş bir metropolitan şehrinde (Bursa'da) kadınlar arasında aile içinde yaşanan evlilik şiddetinin yaygınlığını, tipini, sıklığını ve nedenlerini araştırmışlardır. Çalışma 2003 yılında yatay kesit verisine dayalı olarak gerçekleştirilmiştir. Farklı amaçlar için 50 tane sağlık ocağını ziyaret eden, yaşı 18 ve üzerinde olan evli kadınlar çalışmaya dahil edilmiştir. 1427 anketin 1010 tanesi uygun bulunmuş ve yüz yüze görüşmeyle anketler tamamlanmıştır. Uygulamada çoklu uyum analizi ve logistik regresyon analizi gerçekleştirilmiştir. Aile içi şiddet ve eğitim düzeyi arasında istatistiksel olarak anlamlı bir ilişki bulunmuştur. Eğitimi olmayan kadınlar üniversite mezunu veya daha yüksek eğitime sahip olanlara göre 2.6 kat daha fazla ailevi suistimale uğramıştır. Aile içi şiddet ile kadının yaşı veya iş durumu, evlilik süresi veya aile geliri arasında istatistiksel olarak anlamlı bir ilişki bulunamamıştır. En sık karşılaşılan şiddet türü fiziksel şiddettir, onu duygusal şiddet takip etmektedir. En düşük eğitim düzeyinin ve gelirin, şiddete uğrayan kadınlar arasında sıklıkla tüm şiddet türlerinde görüldügü rapor edilmiştir. Aile içi şiddeti önlemede kızların eğitilmesinin ve eğitimin önemi vurgulanmıştır.

Alper vd. (2005), bir grup Türk kadını arasında yaşanan aile içi şiddet gerçeğini, onun genişliğini, tipini ve yaşanma sıklığını araştırmışlardır. Çalışmayı Ekim 2000 ile Mayıs 2001 döneminde Türkiye'nin en büyük dördüncü şehri olan Bursa'da gerçekleştirmişlerdir. Farklı bölgelerdeki herhangi 50 sağlı merkezini ziyaret eden 15 yaş üzerindeki tüm kadınlar çalışmaya dahil edilmiştir. 506 katılımcı çalışma grubu olarak alınmıştır ve yüz yüze görüşme ile anket formu doldurulmuştur. Ankete katılanların 297 (\%58.7)'sinin hayatlarında en az bir kez aile içi şiddete maruz kaldığ 1 tespit edilmiştir. Erkek arkadaş ilk şiddet uygulayan kişidir ve bunların oranı \% 49.5 'dir. Bunu anne ve/veya babası \%14.1 oranı ile takip etmiştir. Fiziksel ve psikolojik şiddet kombinasyonunun $\% 45.5$ ile en çok karşılaşılan şiddet türü olduğu bulunmuştur. Kadınların yarıdan fazlasının (\%58.6) aile içi şiddeti sıklıkla ve sürekli olarak yaşadığı sonucuna ulaşılmıştır. Şiddet davranışının nedenlerinin ekonomik zorluk (\%18.9), alkol tüketimi (\%18.5) ve kötü aile ilişkileri (\%15.8) olduğu ortaya konmuştur. Mağdurların \%43.8'i şiddeti kabul ederken, \%26.6'sı tepki göstermiştir. Çocukları yüzünden 
eşinin şiddeti nedeniyle ilişkisini bitirmeye istekli olmayan kadınların oranı \%48.2 bulunmuştur. Kadınların ve erkeklerin yüksek eğitimli olmasının aile içi şiddetin yaygınlığında bir düşüşe yol açtığ bulgusu elde edilmiştir.

Kocacık ve Doğan (2006) kadına yönelik aile içi şiddetin nedenlerini Sivas ili için değerlendirmişlerdir. Analizler 10 mahalleden seçilmiş 583 hanehalkı ile 2004 yılında yapılan anketlerden elde edilen bulgular temel alınarak gerçekleştirilmiştir. Elde edilen sonuçlara göre aile içi şiddetin yaygınlığ $\% 52$ oranındadır. Ailenin yıllık gelir seviyesi arttığında aile içi şiddet oranının düştüğü tespit edilmiştir. Düşük eğitim seviyesi de aile içi şiddeti artıran önemli bir unsur olarak bulunmuştur. Şiddete maruz kalan kadınların \%74’ünün ev hanımı olduğu tespit edilmiştir. Bu sonuca istinaden ekonomik özgürlüğün aile içi şiddete karşı koruyucu etkisine vurgu yapılmıştır.

Syed vd. (2013), Pakistan’ın Shikarpur Sindh bölgesinde kadınlara karşı aile içi şiddeti araştırmışlardır. Pakistan'da kadınlar, aile şiddeti en yaygını olmak üzere çeşitli şiddet türleriyle karşı karşıya kalmaktadırlar. Araştırılan kadınların çoğunun temel haklarından mahrum edildiği ve erken evliliklere karşı çıktıkları görülmektedir. Kırsal kesimdeki kadınların daha az kendilerine güven duydukları ve evin dışına çıktıklarında eşlerinin şiddeti ile karşılaştıkları rapor edilmiştir.

Paul (2016), kadının iş gücüne katılımının aile içi şiddet üzerindeki etkilerini Hindistan için analiz etmiştir. Analizlerde 15-49 yaş aralığındaki 69704 evlenmiş kadını kapsayan örneklem kullanılmıştır. Veri kaynağı 2005-2006 yıllarında gerçekleştirilmiş olan Ulusal Aile Sağlığı Anketi III olmaktadır. Analizlerde Doğrusal Olasılık Modeli ve Logistic Regresyon Modeli uygulanmıştır. Analiz sonuçlarına göre çalışan kadının kısa dönemde şiddete uğrama olasılığı işgücüne dahil olmayan kadınlara kıyasla daha yüksektir. Bu sonuç, kadının istihdamıyla birlikte güçsüz bırakılan erkeklerin alışılagelen aile içi düzeninin yeniden tesisi için şiddeti bir araç olarak görmeye başlamasıyla açıklanmaktadır. Bununla birlikte eşinden daha fazla kazanan veya kendi kullanımına ait parası olan kadının da şiddete uğrama olasılığı da daha yüksek bulunmuştur.

Büyükyılmaz ve Demir (2016), Türkiye'de kadına yönelik aile içi şiddeti etkileyen unsurları Multinomial Logit Model analiziyle değerlendirmişlerdir. Ampirik analizlerde Türkiye İstatistik Kurumu'nun (TÜİK) 2008 yılı “Türkiye'de Kadına Yönelik Aile İçi Şiddet Araştırması" veri seti kullanılmıştır. 15-59 yaş arasındaki 2071 kadından elde edilen anket sonuçlarına göre yapılan analizlerde fiziksel şiddet görenler hiç şiddet görmeyenlerle, hem fiziksel hem de cinsel şiddet görenler hiç şiddet görmeyenlerle karşılaştırılarak iki farklı modelleme kullanılmıştır. Elde edilen sonuçlara göre; lise ve üstü eğitim alanlar ilköğretim mezunlarına göre, 14-25 yaş grubundakiler 26 ve üstü yaşta olanlara göre, eşi lise ve üstü eğitim alanlar eşi ilköğretim mezunu olanlara göre, eşi çalışanlar çalışmayanlara göre, eşi alkol kullanmayanlar kullananlara göre, Marmara Bölgesinde yaşayanlar İç Anadolu, Doğu ve 
Güneydoğu Anadolu Bölgesinde yaşayanlara göre daha az fiziksel şiddete maruz kalmaktadır. Hem fiziksel hem cinsel şiddete uğrayanların değerlendirildiği ikinci modelde de bu bulgular desteklenmektedir.

Owusu Adjah ve Agbemafle (2016), Gana'daki evli kadınların aile içi şiddeti yaşama olasılığını arttıran faktörleri belirlemeye çalışmışlardır. 2008 Gana Demografik ve Sağlık Araştırması verilerini kullanarak çok değişkenli logistik model ile çalışmışlar ve risk faktörlerini elde etmişlerdir. Çalışmalarında 1524 evli kadının \%33.6’sı aile içi şiddeti yaşamıştır. Kentsel alanlarda oturan kadınların aile içi şiddeti yaşama riski \%35'dir. Eşinin babasının annesine vurduğuna tanık olan kadınların, babası annesine asla şiddet uygulamayan kadınlara göre, aile içi şiddet görme riski \%41 daha fazladır. Annesinin babasına vurduğuna tanık olan kadınlar diğerlerine göre şiddete 3 kat daha fazla maruz kalmaktadır. Eşi orta öğretim üstü eğitimli olan kadınların, eşi hiç okula gitmeyen kadınlara nazaran aile içi şiddet görme riski \%48 daha azdır. Eşi alkol kullanmayan kadınlarla kıyaslandığında eşi alkol kullanan kadınlar 2.5 kat daha fazla aile içi şiddete maruz kalmaktadır.

Dasre vd. (2017), kadının ekonomik katılımının aile içi şiddeti hangi yönde etkilediğini Türkiye için analiz etmişlerdir. Analizlerde 15-59 yaş aralığındaki evlenmiş kadınlar üzerine odaklanılmış ve 2014 yılında gerçekleştirilen Kadına Yönelik Aile İçi Şiddet Anketinden yararlanılmıştır. Örneklem 6125 kadını kapsamaktadır. Aile içi şiddet kavramı son 12 ayda kadına yakın ilişkide olduğu erkek partneri tarafından uygulanan fiziksel ve/veya cinsel şiddet olarak ele alınmıştır. Ampirik analizlerde Logit Model kullanılmıştır. Analizlerde kadının sosyoekonomik anlamda güçlenmesinin (kadının eğitimi, işgücü piyasasına katılımı, hane gelirine katkısı değişkenleriyle ölçülmüştür) şiddet üzerindeki etkilerine odaklanılmıştır. Yüksek eğitim seviyesinin ve resmi işlerdeki istihdamın kadınları aile içi şiddetten koruduğu bulgusuna ulaşılmıştır. Bununla birlikte eşler arasındaki ekonomik güç dağılımındaki eşitsizliğin aile içi şiddetle sonuçlanabilecek gerginlikler yaratma potansiyeline sahip olduğu gözlenmiştir. Analiz sonuçlarına ilişkin detaylar şu şekilde özetlenebilir: (i) kadının yaşı arttıkça şiddet görme olasılığı azalmaktadır, (ii) çocuk sayısı arttıkça şiddet olasılığı artmaktadır, (iii) rızası dışında evlilik yapan ve yeniden evlenen kadınların şiddet görme olasılığı daha yüksektir, (iv) eşin alkol kullanımı ile şiddet arasında pozitif yönlü ilişki bulunmuştur, (v) yüksek öğretim gören kadınların şiddet görme riski daha düşüktür, (vi) resmi olmayan ya da düzensiz işlerde istihdam edilen kadınların resmi işlerde çalışan veya iş hayatında aktif olmayan kadınlara göre şiddet görme olasılığı daha yüksektir, (vii) ekonomik katılıma ilişkin sınırlı özgürlükler ile şiddet yakın ilişki içerisindedir, (viii) eşinin eğitim seviyesi düşük olan kadınların şiddet görme olasılığı daha yüksektir.

Lenze ve Klasen (2017) de kadının işgücüne katılımının aile içi şiddete etkisini Ürdün için analiz etmişlerdir. Analizler 2007 yılında gerçekleştirilmiş olan Ürdün Nüfus ve Aile Sağlığı Anketi’ne dayanmaktadır. Örneklem 15-49 yaş aralığındaki 10867 evlenmiş kadını içermektedir. Analizlerde Doğrusal Olasılık Modeli kullanılmıştır. Analiz sonuçlarına göre eğer kadın ücretli 
bir işte çalışıyorsa eşinden şiddet görme olasılığı \%7.6 artmaktadır. Eşin eğitim seviyesinin düşük olması durumunda şiddetin arttığı tespit edilmiştir. Eşin düzenli bir işinin olması kadının maruz kaldığı şiddeti istatistiksel olarak anlamlı ve negatif yönde etkilemektedir. Hanehalkının ekonomik statüsünü yansıtan servetin şiddeti azalttığı tespit edilmiştir. İçsellik sorunu göz önüne alınıp tahminler tekrarlandığında kadının çalışma durumunun aile içi şiddet üzerindeki etkisinin anlamsızlaştığı görülmektedir.

\section{Kadının İşgücüne Katılımının Kadına Yönelik Aile İçi Şiddet Üzerindeki Etkisi}

Kadına yönelik aile içi şiddetin önlenebilmesine ilişkin vurgulanması gereken önemli bir husus kadının işgücüne katılımıyla ilgilidir. Kadının işgücüne katılımının aile içi şiddete etkisine ilişkin farklı bakış açıları olmakla birlikte bu konudaki ilk yaklaşım, kadın istihdamının şiddetten koruyucu etkilerine işaret etmektedir. Kadının işgücüne katılımıyla birlikte gelir elde etmesine bağlı olarak sağladığı ekonomik güç aile içindeki şiddeti azaltıcı etkiler yaratacaktır. Kadının finansal bağımsızlığı şiddet gördüğü ilişkisini bitirme olasılığını yükseltecektir. Bununla birlikte kadının gelirindeki bir artış eşin şiddet içeren davranışlarını kısıtlamaktadır. Ayrıca kadının gelir sağlaması ailenin gelirinde bir artışa neden olmak suretiyle ailenin ekonomik stresini azaltmakta ve böylece eş şiddetini engellemektedir. Konuya ilişkin diğer yaklaşımda ise kadının ücretli bir işte istihdamının şiddeti arttıracağı savunulmaktadır. Buna göre kadının çalışma hayatına dahil olmasıyla birlikte kendilerinin aile içindeki otoritesinin sarsıldığını düşünen eşler bu otoritenin yeniden temini için şiddete başvurmaktadırlar (Lenze ve Klasen, 2017, s. 3).

Kadınların ekonomik hayata tam ve etkin olarak katılımı güçlü ekonomilerin inşası ve yaşam kalitesinin geliştirilmesi için son derece önemlidir. Kadınların mevcut durumları iyileştirilmeden kalkınma, sürdürülebilirlik ve insan haklarına yönelik hedeflere ulaşılmasına imkân bulunmamaktadır. Aile içi şiddet geçmişi olan kadınların, iş hayatının daha fazla kesintiye uğradığı ve iş hayatındaki verimliliklerinin azaldığı görülmektedir. Bununla birlikte aile içi şiddet kadınların işgücü içerisinde kalma isteklerini de olumsuz etkilemektedir (Ararat vd., 2014). Kadına yönelik şiddetin düşük kadın işgücü katılımı, düşük iş verimliliği ve düşük kazançlar gibi etkileri olduğu vurgulanmalıdır. ABD'de şiddet mağduru kadınların \%30'unun uğramış oldukları şiddete bağlı olarak işlerini kaybettikleri raporlanmıştır. Bununla birlikte, Santiago için yapılan bir çalışmada şiddete maruz kalmayan kadınların ayda ortalama 385 dolar kazanırken aile içinde fiziksel şiddet gören kadınların aylık ortalama gelirinin ancak 150 dolar olduğu tahmin edilmiştir. Diğer taraftan, aile içi şiddetin çocukların gelecek istihdam olanaklarına potansiyel etkisi de önemlidir. Şiddet yaşanan ailelerden çıkan çocukların eğitim hayatlarında karşılaştıkları kötü performans bir diğer doğrudan etkidir (UNICEF, 2000, s. 9).

Kadına yönelik aile içi şiddetin önlenmesinde, özellikle uzun vadede, kadının eğitim seviyesinin ve kadının işgücüne katılım oranının arttırılmasına yönelik çabaların son derece önemli olduğu düşünülmektedir. Kadın işgücü katılım oranının artması kadının hane içindeki otoritesini arttırıcı ve dolayısıyla aile içi şiddete uğrama riskini de azaltıcı bir unsurdur. Aile içi şiddetin 
varlığı kadının işgücüne katılımını azaltıcı etkiler yaratabileceği gibi, kadının işgücüne katılım oranının artması da aile içi şiddeti önleyici etkiler yaratabilecektir. Nitekim, Yılmaz (2017) Türkiye için gerçekleştirdiği deneye dayalı çalışmasında kadının aile içindeki otoritesinin artmasının aile içi şiddeti azalttığı; kadının aile içi otoritesinin de kadının eğitimi ve kendine ait gelirinin varlığı ile doğru orantılı olduğu bulgusuna ulaşmıştır. $\mathrm{Bu}$ konuya diğer perspektiften yaklaşıldığında ise kadının hane içindeki otoritesinin azalmasının kadının işgücüne katılım oranının azalmasıyla sonuçlanabileceği riskine de vurgu yapmak gerekir.

Kadınların çalışmasına karşı olumsuz bakışın değişmesi, kadınların eğitim seviyesinin yükselmesi, evlilik yaşının yükselmesi ve doğum oranlarının düşmesine rağmen Türkiye’de kadınların işgücüne katılım oranları çok düşüktür. Kentleşme ve tarımsal istihdamdaki azalma kadınların işgücüne katılım oranını azaltmaktadır. Tarımdan, tarım dışı işgücü göçü gerçekleştikçe, kadınların ücretsiz aile işçisi olarak yoğun biçimde istihdam edildiği tarımın istihdamdaki payı azalmış, kadınların işgücüne katılım oranı düşüş eğilimine girmiştir. Bu nedenlerin dışında ekonomik krizler, eğitim seviyesinin düşük olması, çalışma çağındaki nüfusun yıllık artış hızının o yıl içerisinde yeni yaratılan işlerin yıllık artış hızından fazla olması ve enformel ekonominin varlığı da kadınların işgücüne katılım oranlarını azaltmaktadır (Oktay, 2015, s. 81).

Ek Tablo 2'de seçilmiş bazı ülkelerde 2016 yılında kadınların işgücüne katılım oranlarına ilişkin veriler aktarılmaktadır. Uluslararası Çalışma Örgütü (ILO) verilerine göre Türkiye’de kadınların işgücüne katılım oranı 2016 yılı için \%36.2'dır. Tabloda yer verilen 79 ülke arasında Türkiye'nin ancak son sıralarda yer buluyor olması üzerinde düşünülmesi gereken bir bulgudur. Türkiye kadın işgücü katılım oranı bağlamında ancak İran (\%17.5), Kosova (\% 8.6), Suudi Arabistan (\%23.3), Mısır (\%24.1) ve Bangladeş (\%34.2)'in ön sıralarına yerleşebilmiştir. İşgücüne dahil olmayan kadınların \%24'ü hane içinde karar alma sürecinde otoriteleri olmadığını belirtmişlerdir (Yılmaz, 2017, s. 21). Kadın işgücü katılım oranında bu kadar alt sıralarda yer alan Türkiye, 2015 yılında UNSTATS'ın yayınladığı istatistiklere ${ }^{4}$ göre kadına yönelik şiddetin yaygınlı̆̆ı sıralamasında ise üst sıralara yerleşmektedir.

Tablo 3'de Türkiye'de kadınların işgücüne katılım oranının yıllar içinde değişimi gösterilmektedir. 2006 yılında \%25.1 olan kadın işgücüne katılım oranının 2016 yılında \%36.2'ye yükselmesi olumlu bir gelişme olsa da daha önemli bir gelişme sağlaması gerektiği ortadadir.

Tablo 3. Türkiye'de Kadınların İşgücüne Katılım Oranı (15-64 yaş)

\begin{tabular}{|l|l|l|l|l|l|l|l|l|l|l|l|}
\hline & $\mathbf{2 0 0 6}$ & $\mathbf{2 0 0 7}$ & $\mathbf{2 0 0 8}$ & $\mathbf{2 0 0 9}$ & $\mathbf{2 0 1 0}$ & $\mathbf{2 0 1 1}$ & $\mathbf{2 0 1 2}$ & $\mathbf{2 0 1 3}$ & $\mathbf{2 0 1 4}$ & $\mathbf{2 0 1 5}$ & $\mathbf{2 0 1 6}$ \\
\hline $\begin{array}{l}\text { Kadın } \\
\text { İş̧gücüne } \\
\text { Katılım Oranı }\end{array}$ & 25.1 & 25.2 & 26.2 & 27.8 & 29.6 & 31 & 31.8 & 33.2 & 33.6 & 34.9 & 36.2 \\
\hline
\end{tabular}

Kaynak: http://www.ilo.org/ilostat/ (Erișim Tarihi: 05.02.2018)

\footnotetext{
${ }^{4}$ Ek kısmında Tablo 1'de ilgili istatistiki bilgiler sunulmaktadır.
} 


\section{Ampirik Analiz}

\section{Verilerin ve Değişkenlerin Tanımlanması}

Çalışmada TÜİK’in 2008 ve 2014 yıllarında yaptı̆̆g “Türkiye'de Kadına Yönelik Aile İçi Şiddet Araştırması” ham verileri kullanılarak, Türkiye'de kadına yönelik aile içi şiddeti etkileyen faktörler incelenmiş ve söz konusu yıllar için karşılaştırma yapılmıştır. Kadına yönelik şiddet konusunda yürütülmüş ülke çapında temsil niteliğine sahip kapsamlı ilk araştırma TÜİK tarafından 2008 yılında gerçekleştirilen “Türkiye’de Kadına Yönelik Aile İçi Şiddet Araştırması”dır. 2014 yılında yapılan “Türkiye’de Kadına Yönelik Aile İçi Şiddet Araştırması”, kadınların yaşadığı aile içi şiddetin büyüklüğü, içeriği, neden ve sonuçları ile risk faktörlerinin anlaşılması amacıyla ülke genelini temsil eden en geniş örneklemli ikinci araştırmadır (TÜİK). 2008 yılındaki anket 12795 kadınla, 2014 yılındaki anket ise 7462 kadınla gerçekleştirilmiştir. 2014 yılındaki araştırmada 666 kadın anket sorularının çoğunu cevaplamayı reddettiği için bu çalışmada 6796 kadın analize dahil edilmiştir. Her iki yıl için yapılan anketlere 15-59 yaş arasındaki kadınlar katılmıştır. Kadının aile içinde şiddet görmesini etkileyen faktörler olarak; kadının yaşı, kadının ve eşinin eğitim düzeyi, kadının ve eşinin çalışma durumu, eşinin alkol kullanması, kumar oynaması, uyuşturucu kullanması, 6-14 yaş aralığındaki çocuk sayısı ve hanenin yaşadığı bölge alınmıştır. Kadının işgücüne katılımını temsil eden değişken, anketlerin özelliğinden dolayı sadece kadının çalışma durumu (çalışıyor veya çalışmıyor) olarak seçilebilmiştir. Her iki yıl için yapılan anketlerde "düzenli işiniz var mı?” sorusuna "evet" cevabını veren kadınlar, çalışıyor olarak değerlendirilmiştir. Bağımlı değişken, fiziksel ya da cinsel şiddet gören ve görmeyen kadınlar şeklinde iki kategorili olarak ele alınmıştır. Analizde kullanılan tüm değişkenler ve tanımlayıcı istatistikleri Tablo 4'de verilmiştir. 
Tablo 4. Tanımlayıcı İstatistikler

\begin{tabular}{|c|c|c|c|c|c|c|}
\hline & \multicolumn{3}{|c|}{2008} & \multicolumn{3}{|c|}{2014} \\
\hline & $\mathbf{N}$ & Ort. & Std. Sap. & $\mathbf{N}$ & Ort. & Std. Sap. \\
\hline \multicolumn{7}{|l|}{ Kadının Yaşı } \\
\hline $15-25$ & 3145 & 0.246 & 0.431 & 1021 & 0.150 & 0.357 \\
\hline $26-35$ & 3991 & 0.312 & 0.463 & 2117 & 0.312 & 0.463 \\
\hline $36-45$ & 2931 & 0.229 & 0.420 & 1784 & 0.263 & 0.440 \\
\hline $46-59$ & 2728 & 0.213 & 0.409 & 1874 & 0.276 & 0.447 \\
\hline \multicolumn{7}{|l|}{$\begin{array}{l}\text { Kadının Eğitim } \\
\text { Düzeyi }\end{array}$} \\
\hline $\begin{array}{l}\text { Okula gitmeyenler ve } \\
\text { ilköğretim }\end{array}$ & 9410 & 0.735 & 0.441 & 4886 & 0.719 & 0.449 \\
\hline Lise ve üstü & 3385 & 0.265 & 0.441 & 1910 & 0.281 & 0.449 \\
\hline \multicolumn{7}{|l|}{$\begin{array}{l}\text { Kadının Çalışma } \\
\text { Durumu }\end{array}$} \\
\hline Çalışıyor & 3400 & 0.266 & 0.442 & 2123 & 0.312 & 0.464 \\
\hline Çalışmıyor & 9395 & 0.734 & 0.442 & 4673 & 0.688 & 0.464 \\
\hline \multicolumn{7}{|l|}{ Eşinin Eğitim Düzeyi } \\
\hline $\begin{array}{l}\text { Okula gitmeyenler ve } \\
\text { ilköğretim }\end{array}$ & 8308 & 0.649 & 0.477 & 4016 & 0.591 & 0.492 \\
\hline Lise ve üstü & 4487 & 0.351 & 0.477 & 2780 & 0.409 & 0.492 \\
\hline \multicolumn{7}{|l|}{$\begin{array}{l}\text { Eşinin Çalışma } \\
\text { Durumu }\end{array}$} \\
\hline Çalışıyor & 9616 & 0.752 & 0.432 & 5468 & 0.805 & 0.397 \\
\hline Çalışmıyor & 3179 & 0.248 & 0.432 & 1328 & 0.195 & 0.397 \\
\hline \multicolumn{7}{|l|}{$\begin{array}{l}\text { Eşinin Alkol } \\
\text { Kullanması }\end{array}$} \\
\hline Kullaniyor & 2472 & 0.193 & 0.395 & 1365 & 0.201 & 0.401 \\
\hline Kullanmiyor & 10323 & 0.807 & 0.395 & 5431 & 0.799 & 0.401 \\
\hline \multicolumn{7}{|l|}{$\begin{array}{l}\text { Eşinin Kumar } \\
\text { Oynaması }\end{array}$} \\
\hline Oynuyor & 247 & 0.019 & 0.138 & 136 & 0.020 & 0.140 \\
\hline Oynamiyor & 12548 & 0.981 & 0.138 & 6660 & 0.979 & 0.140 \\
\hline \multicolumn{7}{|l|}{$\begin{array}{l}\text { Eşinin Uyuşturucu } \\
\text { Kullanması }\end{array}$} \\
\hline Kullaniyor & 40 & 0.003 & 0.056 & 42 & 0.006 & 0.078 \\
\hline Kullanmiyor & 12755 & 0.997 & 0.056 & 6754 & 0.994 & 0.078 \\
\hline \multicolumn{7}{|l|}{ 6-14 Yaş Arası Çocuk } \\
\hline Var & 5238 & 0.409 & 0.492 & 3027 & 0.445 & 0.497 \\
\hline Yok & 7557 & 0.591 & 0.492 & 3769 & 0.555 & 0.497 \\
\hline \multicolumn{7}{|l|}{ Bölgeler } \\
\hline Marmara & 2715 & 0.212 & 0.409 & 1897 & 0.279 & 0.449 \\
\hline Ege & 989 & 0.077 & 0.267 & 584 & 0.086 & 0.280 \\
\hline İç Anadolu & 2057 & 0.161 & 0.367 & 988 & 0.145 & 0.353 \\
\hline Akdeniz & 1151 & 0.089 & 0.286 & 561 & 0.083 & 0.275 \\
\hline Karadeniz & 1965 & 0.154 & 0.361 & 1173 & 0.173 & 0.378 \\
\hline Doğu Anadolu & 2502 & 0.196 & 0.397 & 1105 & 0.163 & 0.369 \\
\hline Güneydoğu Anadolu & 1416 & 0.111 & 0.314 & 488 & 0.072 & 0.258 \\
\hline
\end{tabular}


Tablo 5'de 2008 ve 2014 yıllarında hanenin bulunduğu yerleşim yerine göre şiddet gören ve görmeyen kadınların frekansları ve yüzdeleri verilmiştir. 2008 yılında kentte yaşayan kadınların \%62.73'ü şiddet görmezken, \%37.27’si şiddet görmüştür. Yine aynı yılda kırsal alanda yaşayan kadınların \%59.39'u şiddete maruz kalmamış fakat \%40.61'i ya fiziksel ya da cinsel şiddete maruz kalmıştır. 2008 yılında kırsal bölgelerde oturan kadınlar kentsel bölgelerdekilere göre daha fazla şiddet görmüştür. 2014 yılına bakıldığında kentte oturan kadınların \%66.09'u şiddet yaşamaz iken, \%33.91'i şiddet yaşamıştır. Eşi tarafından şiddete uğramayan kadınların oranı söz konusu yıl için kırsal alanda \%63.59, şiddete uğrayan kadınların oranı \%36.41'dir. 2008 yılında olduğu gibi 2014 yılında da kırsal bölgelerde oturan kadınlar kentsel bölgelerde oturanlara göre daha fazla şiddete uğramıştır. Her iki yıl karşılaştırıldığında, 2014 yılında 2008 yılına göre eşi tarafından şiddete uğrayan kadınların oranı kentsel ve kırsal alanlarda daha azdır.

Tablo 5. Yerleşim Yerine Göre Şiddet Gören ve Görmeyen Kadınların Frekansları

\begin{tabular}{|l|l|l|l|l|l|l|l|l|}
\hline & \multicolumn{3}{|c|}{2008} & \multicolumn{3}{c|}{2014} & \multicolumn{2}{l|}{ Kent } \\
\hline & Kent & Kır & N & \\
\hline Şiddet & N & \% & N & \% & N & \% & N & \% \\
\hline $\begin{array}{l}\text { Fiziksel veya } \\
\text { Cinsel Şiddet } \\
\text { Görmemiş }\end{array}$ & 5918 & 62.73 & 1996 & 59.39 & 3083 & 66.09 & 1355 & 63.59 \\
\hline $\begin{array}{l}\text { Fiziksel veya } \\
\text { Cinsel Şiddet } \\
\text { Görmüş }\end{array}$ & 3516 & 37.27 & 1365 & 40.61 & 1582 & 33.91 & 776 & 36.41 \\
\hline Toplam & 9434 & & 3361 & & 4665 & & 2131 & \\
\hline
\end{tabular}

\section{Yöntem}

Bağımlı değişkenin iki durumlu olduğu (0 veya 1 değerini aldığı) modeller kesikli seçim modelleri olarak bilinirler. Doğrusal olasılık modeli, probit ve logit modelleri kesikli seçim modelleridir. Çalışmanın uygulama kısmında ele alınan bağımlı değişken, fiziksel veya cinsel şiddet gören ve görmeyen kadınlardır. Bu değişken, iki durumlu kalitatif bir değişkendir. $\mathrm{Bu}$ nedenle analiz logit model kullanılarak gerçekleştirilmiştir. Logit model şu şekilde tanımlanmaktadır (Davidson ve MacKinnon, 1999: 446; Studenmund, 1997: 510):

$$
P_{i}=E\left(Y=1 / X_{i}\right)=\frac{1}{1+e^{-\left(\beta^{\prime} x_{i}\right)}}
$$

eşitliğinde $Z_{i}=\beta^{\prime} x_{i}$ olarak alınırsa,

$$
P_{i}=E\left(Y=1 / X_{i}\right)=\frac{1}{1+e^{-z_{i}}}
$$

(2) denklemi, kümülatif logistik dağılım fonksiyonu olarak bilinmektedir (Brooks, 2008 : 514; Dhrymes, 1978: 328). Bağımlı değişkenin $-\infty$ ve $+\infty$ arasında herhangi bir değer alabildiği farz 
edilmektedir. Ancak bu durum dışında, sadece sonlu sayıda değerler de alabilmektedir. $Z_{i} \rightarrow+\infty$ a giderken $e^{-Z_{i}}$ sıfıra gider. $Z_{i} \rightarrow-\infty$ a giderken $e^{-Z_{i}}$ tanımsız olarak artar. $Z_{i},-\infty$ dan $+\infty$ a doğru giderken $P_{i}, 0$ ile 1 aralığındadır. $P_{i} \quad[0,1]$ aralığının dışında asla olamaz (Intriligator, vd., 1996: 161; Ramanathan, 1998: 607). Tahmin yöntemi, gözlemlenen P'nin 0 ve 1 arasında olup olmamasına veya iki değerli olup olmamasına ve 0 ya da 1 değerlerini alıp almamasına dayanmaktadır. P'nin kesinlikle 0 ve 1 arasında olduğu durumda, yöntem P'yi dönüştürüp bağımlı değişkeni kolayca elde edebilmektedir. Daha sonra bağımlı değişken, sabit terim ve açılayıcı değişken (ya da açıklayıcı değişkenler) üzerine regres edilmektedir (Ramanathan, 1998: 607). $P_{i}$ ile $Z_{i}$ arasında doğrusal olmayan bir ilişki vardır. Bu yüzden parametreleri tahmin etmek için EKKY kullanılamaz, doğrusal olmayan tahmin yöntemleri kullanılabilir. Kümülatif logistik dağılım fonksiyonunun tersi alınarak logit model doğrusallaştırılabilir (Gujarati, 2004: 555).

$$
\begin{aligned}
1-P_{i} & =\frac{1}{1+e^{-z_{i}}} \\
\frac{P_{i}}{1-P_{i}} & =\frac{1+e^{z_{i}}}{1+e^{-z_{i}}}=e^{z_{i}}
\end{aligned}
$$

yazılabilir. $P_{i} / 1-P_{i}$, fark oranıdır. Fark oranının doğal logaritması alınırsa, hem parametrelerine hem de değişkenlerine göre doğrusal denklem elde edilmektedir. Yani fark oranının logaritması, yalnız $x_{i}^{\prime}$ 'lere göre değil anakütle katsayılarına göre de doğrusaldır (Koop, 2008: 278; Maddala, 1992: 328):

$\ln \left(\frac{P_{i}}{1-P_{i}}\right)=\ln \left(e^{z_{i}}\right)=Z_{i}=\beta^{\prime} x_{i}$

$Z_{i}=\beta^{\prime} x_{i}$ denklemine logit model denir.

\section{Ampirik Sonuçlar}

2008 ve 2014 yıllarında Türkiye'de kadına yönelik aile içi şiddeti etkileyen faktörleri belirlemek için oluşturulan Logit modelin tahmin sonuçları ve marjinal etkileri Tablo 6'da sunulmuştur. Tablo 6'da her bir yıla ait ilk sütun logit modelin katsayı değerlerini, ikinci sütun katsayıların z istatistiklerini, üçüncü sütun marjinal etkileri ve dördüncü sütun bunların $\mathrm{z}$ istatistik değerlerini vermektedir. Modeller marjinal etkiler dikkate alınarak yorumlanacaktır.

Analiz sonuçlarına göre, 2008 ve 2014 yıllarında 15-25 yaş arasındaki kadınlara göre 26-35, 3645 ve 46-59 yaş arasındaki kadınlar daha fazla şiddet görmektedir. Eğitim düzeyi lise ve üzerinde olan kadınlar, hiç okula gitmemiş ya da ilköğretim mezunu olan kadınlara göre 2008 yılında \%17.7, 2014 yılında \%12.7 daha az şiddete maruz kalmıştır. Benzer şekilde lise ve üzerinde eğitimi olan erkekler hiç okula gitmemiş ya da ilköğretim mezunu olan erkeklere nazaran eşlerine, 2008 yılında \%5.7, 2014 yılında \%10.1 daha az şiddet uygulamıştır. Kadının işgücüne katılımının aile içi şiddete etkisine ilişkin farklı bakış açıları olduğu, bazı yaklaşımlara 
göre aile içi şiddeti azalttığına bazı yaklaşımlara göre ise aile içi şiddeti arttırdığına dair değerlendirmelere çalışmanın üçüncü bölümünde yer verilmiştir. Logit model bulgularına göre kadının çalışıyor olması şiddet görmesini engelleyen bir faktör değildir. İsgücüne dahil olan yani çalışan kadınlar çalışmayan kadınlara göre 2008 ve 2014 yıllarında \%2.9 ve \%2.4 daha fazla fiziksel ya da cinsel şiddet yaşamıştır. Diğer taraftan, eşi çalışan kadınlar eşi çalışmayan kadınlara oranla 2008 ylında daha fazla şiddet görmüştür. 2014 yllı için eşin çalışıyor olması istatistiksel olarak anlamlı değildir. Kadının eşinin veya birlikte yaşadığı kişinin alkol kullanması, kumar oynaması ve uyuşturucu kullanması ciddi boyutlarda kadına şiddet uygulamasına neden olmaktadır. Her iki modelde de sırasıyla eşi alkol kullanan kadınlar kullanmayanlara göre \%15.7 ve \%16.6, eşi kumar oynayan kadınlar oynamayan kadınlara nispeten \%26.8 ve \%34.8, eşi uyuşturucu kullanan kadınlar kullanmayanlara nazaran \%40.4 ve \%39.4 daha fazla şiddete maruz kalmıştır. Yaşları 6 ile 14 arasında değişen çocukların olması durumunda kadınların şiddet görmesi olasılığı daha fazladır. Hanenin yaşadığı bölge açısından bakıldığında 2008 yllında Ege bölgesinde, 2014 yllında Karadeniz ve Güneydoğu Anadolu bölgelerinde oturmanın fiziksel veya cinsel şiddet üzerinde bir etkisinin olmadığ görülmektedir. Ancak bunlar dışında, her iki modelde de Marmara bölgesiyle kıyaslandığında diğer bölgelerde yaşayan kadınların daha fazla şiddet gördüğü ortaya çıkmıştır. Marmara bölgesine göre en fazla şiddetin yaşandığı bölge 2008 yllında \%20.2 ile Doğu Anadolu bölgesi, 2014 yllında \%12.8 ile İç Anadolu bölgesidir. Çalışmadan elde edilen sonuçlar, Dasre vd. (2017), Lenze ve Klasen (2017), Paul (2016) ve Alper vd. (2005)'nin bulgularını desteklemektedir. 
Tablo 6. Logit Model Tahmin Sonuçları ve Marjinal Etkileri

\begin{tabular}{|c|c|c|c|c|c|c|c|c|}
\hline & \multicolumn{4}{|c|}{2008} & \multicolumn{4}{|c|}{2014} \\
\hline Bağımlı Değiş̧ken & \multicolumn{4}{|c|}{$\begin{array}{l}\text { Fiziksel veya cinsel şiddet gören ve görmeyen } \\
\text { kadınlar }\end{array}$} & \multicolumn{4}{|c|}{$\begin{array}{l}\text { Fiziksel veya cinsel şiddet gören ve görmeyen } \\
\text { kadınlar }\end{array}$} \\
\hline $\begin{array}{l}\text { Bağımsızz } \\
\text { Değişkenler }\end{array}$ & Katsayı & $\bar{z}$ & $\begin{array}{c}\text { Marjinal } \\
\text { Etki }\end{array}$ & $\bar{Z}$ & Katsayı & $\mathbf{z}$ & $\begin{array}{c}\text { Marjinal } \\
\text { Etki }\end{array}$ & $\overline{\mathbf{z}}$ \\
\hline \multicolumn{9}{|l|}{ Kadının Yaşı } \\
\hline $15-25(\mathrm{TS})$ & & & & & & & & \\
\hline $26-35$ & 0.473 & $7.22^{\mathrm{a}}$ & 0.111 & $7.15^{\mathrm{a}}$ & 0.432 & $4.18^{\mathrm{a}}$ & 0.098 & $4.11^{\mathrm{a}}$ \\
\hline $36-45$ & 0.601 & $8.83^{\mathrm{a}}$ & 0.143 & $8.69^{\mathrm{a}}$ & 0.476 & $4.53^{\mathrm{a}}$ & 0.109 & $4.43^{\mathrm{a}}$ \\
\hline $46-59$ & 1.149 & $18.00^{\mathrm{a}}$ & 0.276 & $18.34^{\mathrm{a}}$ & 0.749 & $7.44^{\mathrm{a}}$ & 0.173 & $7.30^{\mathrm{a}}$ \\
\hline \multicolumn{9}{|l|}{$\begin{array}{l}\text { Kadının Eğitim } \\
\text { Düzeyi }\end{array}$} \\
\hline \multicolumn{9}{|l|}{$\begin{array}{l}\text { Okula gitmeyenler } \\
\text { ve ilköğretim (TS) }\end{array}$} \\
\hline Lise ve üstü & -0.824 & $-14.55^{\mathrm{a}}$ & -0.177 & $-16.06^{a}$ & -0.605 & $-7.80^{\mathrm{a}}$ & -0.127 & $-8.33^{\mathrm{a}}$ \\
\hline \multicolumn{9}{|l|}{$\begin{array}{l}\text { Kadının Çalışma } \\
\text { Durumu }\end{array}$} \\
\hline \multicolumn{9}{|l|}{ Çalışmıyor (TS) } \\
\hline Çalışıor & 0.124 & $2.73^{\mathrm{a}}$ & 0.029 & $2.71^{\mathrm{a}}$ & 0.106 & $1.79^{\mathrm{c}}$ & 0.024 & $1.78^{\mathrm{c}}$ \\
\hline \multicolumn{9}{|l|}{$\begin{array}{l}\text { Eşinin Eğitim } \\
\text { Düzeyi }\end{array}$} \\
\hline \multicolumn{9}{|l|}{$\begin{array}{l}\text { Okula gitmeyenler } \\
\text { ve ilköğretim (TS) }\end{array}$} \\
\hline Lise ve üstü & -0.252 & $-5.37^{\mathrm{a}}$ & -0.057 & $-5.44^{\mathrm{a}}$ & -0.461 & $-7.23^{\mathrm{a}}$ & -0.101 & $-7.40^{\mathrm{a}}$ \\
\hline \multicolumn{9}{|l|}{$\begin{array}{l}\text { Eşinin Çalışma } \\
\text { Durumu }\end{array}$} \\
\hline \multicolumn{9}{|l|}{ Çalışmıyor (TS) } \\
\hline Çalışıyor & 0.348 & $6.94^{\mathrm{a}}$ & 0.078 & $7.17^{\mathrm{a}}$ & -0.004 & -0.06 & -0.001 & -0.06 \\
\hline \multicolumn{9}{|l|}{$\begin{array}{l}\text { Eşinin Alkol } \\
\text { Kullanması }\end{array}$} \\
\hline \multicolumn{9}{|l|}{ Kullanmiyor (TS) } \\
\hline Kullaniyor & 0.654 & $12.62^{\mathrm{a}}$ & 0.157 & $12.38^{\mathrm{a}}$ & 0.712 & $10.20^{\mathrm{a}}$ & 0.166 & $9.91^{\mathrm{a}}$ \\
\hline \multicolumn{9}{|l|}{$\begin{array}{l}\text { Eşinin Kumar } \\
\text { Oynaması }\end{array}$} \\
\hline \multicolumn{9}{|l|}{ Oynamıyor (TS) } \\
\hline Oynuyor & 1.101 & $7.01^{\mathrm{a}}$ & 0.268 & $7.29^{\mathrm{a}}$ & 1.451 & $6.76^{\mathrm{a}}$ & 0.348 & $7.36^{\mathrm{a}}$ \\
\hline \multicolumn{9}{|l|}{$\begin{array}{l}\text { Eşinin Uyuşturucu } \\
\text { Kullanması }\end{array}$} \\
\hline \multicolumn{9}{|l|}{ Kullanmıyor (TS) } \\
\hline Kullaniyor & 1.752 & $4.21^{\mathrm{a}}$ & 0.404 & $5.38^{\mathrm{a}}$ & 1.674 & $4.37^{\mathrm{a}}$ & 0.394 & $5.15^{\mathrm{a}}$ \\
\hline \multicolumn{9}{|l|}{$\begin{array}{l}\text { 6-14 Yaş Arası } \\
\text { Çocuk }\end{array}$} \\
\hline \multicolumn{9}{|l|}{ Yok (TS) } \\
\hline Var & 0.521 & $10.75^{\mathrm{a}}$ & 0.121 & $10.72^{\mathrm{a}}$ & 0.350 & $5.34^{\mathrm{a}}$ & 0.078 & $5.33^{\mathrm{a}}$ \\
\hline \multicolumn{9}{|l|}{ Bölgeler } \\
\hline Marmara (TS) & & & & & & & & \\
\hline Ege & 0.092 & 1.08 & 0.022 & 1.07 & 0.208 & $2.00^{\mathrm{b}}$ & 0.047 & $1.95^{\mathrm{b}}$ \\
\hline İç Anadolu & 0.745 & $11.38^{\mathrm{a}}$ & 0.179 & $11.19^{\mathrm{a}}$ & 0.547 & $6.36^{\mathrm{a}}$ & 0.128 & $6.14^{\mathrm{a}}$ \\
\hline Akdeniz & 0.388 & $4.90^{\mathrm{a}}$ & 0.093 & $4.77^{\mathrm{a}}$ & 0.250 & $2.38^{b}$ & 0.057 & $2.31^{b}$ \\
\hline Karadeniz & 0.377 & $5.62^{\mathrm{a}}$ & 0.089 & $5.50^{\mathrm{a}}$ & -0.092 & -1.09 & -0.020 & -1.10 \\
\hline Doğu Anadolu & 0.840 & $13.17^{\mathrm{a}}$ & 0.202 & $13.04^{\mathrm{a}}$ & 0.223 & $2.59^{\mathrm{b}}$ & 0.051 & $2.54^{\mathrm{b}}$ \\
\hline Güneydoğu Anadolu & 0.791 & $10.65^{\mathrm{a}}$ & 0.192 & $10.51^{\mathrm{a}}$ & 0.102 & 0.89 & 0.023 & 0.88 \\
\hline Sabit & -1.931 & $-25.18^{\mathrm{a}}$ & & & -1.319 & $-11.05^{\mathrm{a}}$ & & \\
\hline $\mathrm{N}$ & & & & & & & & \\
\hline Pseudo & & & & & & & & \\
\hline Log Likelîhood & & & 778 & & & & 343 & \\
\hline $\begin{array}{l}\text { LR chi2 } \\
\text { Prob }>\text { chi2 }\end{array}$ & & & & & & & & \\
\hline
\end{tabular}




\section{Sonuç}

Günümüzde üzerinde en çok tartışılan konuların başında kadına yönelik şiddet gelmektedir. Türkiye'de özellikle son yıllarda kadına yönelik artan şiddet olayları çok dikkat çekmektedir. Bu çalışmada da, kadına yönelik aile içi şiddetin belirleyicileri ve boyutları ortaya konmaya çalışılmış ve kadının işgücüne katılımının aile içi şiddeti nasıl etkilediğine ilişkin değerlendirmeler yapılmıştır.

Çalışmanın uygulama kısmında elde edilen analiz sonuçlarına göre kadına karşı aile içi şiddet üzerinde etkili olan faktörler, kadının yaşı, kadının ve eşinin eğitim düzeyi, kadının işgücüne dahil olması, eşinin alkol kullanması, kumar oynaması ve uyuşturucu kullanması ve hanenin yaşadığı bölgedir. 15-25 yaş arasındaki kadınlara göre 2008 ve 2014 yıllarında 26-35, 36-45 ve 46-59 yaş arasındaki kadınlar daha fazla şiddet görmektedir. Kadının yaşı arttıkça kadına yönelik şiddetin de arttığı sonucuna ulaşılmıştır. Eğitim durumu şiddet üzerinde etkili olan en önemli değişkenlerden birisi olarak kabul edilmektedir. Kadının ve eşinin eğitim düzeyi arttıkça aile içi şiddet azalmaktadır. Lise ve üzerinde eğitime sahip olan kadınlar, hiç okula gitmemiş ya da ilköğretim mezunu olan kadınlara göre daha az fiziksel veya cinsel şiddete maruz kalmaktadır. Aynı şekilde eğitim düzeyi lise ve üzerinde olan eşler daha az şiddet uygulamaktadırlar. Çalışmada yapılan analizlerde üzerinde durulan önemli bir değişken olan kadının çalışmasının yani işgücüne katılıyor olmasının, aile içinde yaşanan fiziksel veya cinsel şiddet üzerindeki etkisini ortaya koyan dikkat çekici bir sonuçla karşılaşılmaktadır. Kadının çalışması, şiddet görmesini azaltan değil arttıran bir unsur olarak karşımıza çıkmaktadır. Logit model sonuçlarına göre çalışan kadınlar genel olarak çalışmayan kadınlara göre 2008 yılında \%2.9 ve 2014 yılında \%2.4 daha fazla fiziksel ya da cinsel şiddet yaşamıştır. Erkeklerin alkol kullanması, kumar oynaması ve uyuşturucu kullanması durumunda şiddetin boyutu çok yükselmektedir. Özellikle eşi uyuşturucu kullanan kadınlar kullanmayanlara nazaran 2008 yılında \%40.4, 2014 yılında \%39.4 daha fazla şiddete maruz kalmaktadır. Bölgesel farklılıklar değerlendirildiğinde, Marmara bölgesine göre en fazla aile içi şiddetin yaşandığı bölge 2008 yılında Doğu Anadolu bölgesi, 2014 yılında İç Anadolu bölgesidir. Çalışmadan elde edilen sonuçların, ülkemizde bu konuda az sayıdaki literatüre katkı sağlayacağı düşünülmektedir. Ayrıca elde edilen analiz bulguları kapsamında Türkiye'de kadına yönelik fiziksel veya cinsel şiddetin yukarıda sözü edilen birçok faktörden etkilendiği ve bu durumda da ülkemizde kadına yönelik şiddetin önlenmesi için geliştirilecek strateji, plan ve politikalarda söz konusu faktörlerin dikkate alınması gerektiği önerilmektedir. 


\section{Kaynakça}

Adaçay, F. R. ve Güney, G. (2012). "Kadına Yönelik Ekonomik Şiddet”, Uluslararası Katılımlı Kadına ve Çocuğa Karşı Şiddet Sempozyumu Bildiri Kitabı, I. Cilt, 312- 328.

Alper, Z., Ergin, N., Selimoğlu, K. ve Bilgel, N. (2005). Domestic Violence: A Study Among a Group of Turkish Women. European Journal of General Practice, 11(2), 48-54.

Ararat, M., Alkan, S., Bayazıt, M., Yüksel, A. ve Budan, P. (2014). Domestic Violence Against White-Collar Working Women in Turkey. http://research.sabanciuniv. edu/25972/1/BADV_Report.pdf. (15.03.2018).

Brooks, C. (2008). Introductory Econometrics for Finance. New York: Cambridge University Press.

Büyükyılmaz, A. ve Demir, Ç. (2016). Türkiye'de Kadına Yönelik Aile İçi Şiddetin Belirleyenleri: Multinomial Logit Model Yaklaşımı. Ege Akademik Bakış, 16(3), 443-450.

Dasre, A., Greulich, A. ve Inan, C. (2017). Combating Domestic Violence Against Women in Turkey. The Role of Women's Economic Empowerment. Documents de travail du Centre d'Economie de la Sorbonne 2017.52 - ISSN: 1955-611X. 2017. <halshs01660703>https://halshs.archives-ouvertes.fr/halshs-01660703/file/17052. pdf (14.03.2018)

Davidson, R. ve Mackinnon, J. G. (1999). Econometric Theory and Methods. New York: Oxford University Press.

Dhrymes, P. J. (1978). Introductory Econometrics. New York: Springer-Verlag.

Dünya Sağlık Örgütü (2002). World Report on Violence and Health. <http://www.who.int/violence_injury_prevention/violence/world_report/en/summary_ en.pdf. (15.03.2018).

Ergin, N., Bayram, N., Alper, Z., Selimoğlu, K. ve Bilgel, N. (2005). Domestic Violence: A Tragedy Behind the Doors. Women\&Health, 42(2), 35-51

Gujarati, D. (2004). Basic Econometrics. U.S.A: The McGraw-Hill.

ILO, http://www.ilo.org/ilostat/ (15.03.2018)

Intriligator, M. D., Bodkin, R. G. ve Hsiao, C. (1996). Econometric Models, Techniques and Applications. U.S.A: Prentice Hall.

Kadın Cinayetlerini Durduracağız Platformu, http://kadincinayetlerinidurduracagiz.net (15.03.2018)

Karal, D. ve Aydemir, E. (2012). Türkiye'de Kadına Yönelik Şiddet. Uluslararası Stratejik Araştırmalar Kurumu (USAK) Yayını, Rapor No: 12-01, Ankara: USAK

Kocacık, F. ve Doğan, O. (2006). Domestic Violence Against Women in Sivas, Turkey: Survey Study. Public Health, 47, 742-749

Koop, G. (2003). Bayesian Econometrics. England: John Wiley\&Sons.

Lenze, J. ve Klasen, S. (2017). Does Women's Labor Force Participation Reduce Domestic Violence? Evidence from Jordan. Feminist Economics, 23(1), 1-29

Maddala, G. S. (1992). Introduction to Econometrics. U.S.A: Macmillan Publishing Company. 
Mayda, A.S. ve Akkuş, D. (2004). Domestic Violence Against 116 Turkish Housewives: A Field Study. Women\&Health, 40(3), 95-108

Oktay, E.Y. (2015). Türkiye'nin ve Dünyanın Ortak Sorunu: Kadına Şiddet. Akademik Araştırmalar Dergisi, 64, 57-118

Owusu Adjah, E.S. ve Agbemafle, I. (2016). Determinants of Domestic Violence Against Women in Ghana. Public Health, 16(368), 1-9.

Paul, S. (2016). Women's Labour Force Participation and Domestic Violence: Evidence from India. Journal of South Asian Development, 11(2), 224-250

Ramanathan, R. (1998). Introductory Econometrics with Applications. U.S.A: Harcourt Brace \&Company.

Studenmund, A. H. (1997). Using Econometrics: A Practical Guide. U.S.A: Addison-Wesley Educational Publishers.

Syed, A.A.S.G., Shaikh, F.M., Halepoto, A.H. ve Shah, A.S. (2013). Domestic Violence Against Women: A Case Study of Shikarpur, Sindh Pakistan. International Journal of Business and Public Administration, 10(1), 114-127

TÜİK, Türkiye'de Kadına Yönelik Aile İçi Şiddet Araştırması, 2008 Mikro Veri Seti

TÜİK, Türkiye'de Kadına Yönelik Aile İçi Şiddet Araştırması, 2014 Mikro Veri Seti

UNICEF (2000). Domestic Violence Against Women and Girls, Innocenti Digest, No:6, https://www.unicef-irc.org/publications/pdf/digest6e.pdf. (14.03.2018)

UNSTATS (2015). The World's Women 2015: Trends and Statistics. New York: United Nations, Department of Economic and Social Affairs, Statistics Division. Sales No. E.15.XVII.8, Statistical https://unstats.un.org/unsd/gender/chapter6/chapter6.html. (14.03.2018)

Annex,

Yllmaz, O. (2017). Women's Autonomy, Social Norms and Intimate Partner Violence Against Women in Turkey. https:/editorialexpress.com/cgiin/conference/download.cgi?db_name=ESPE2015\&paper_id=402. (14.03.2018) 
Ek

Tablo 1. Seçilmiş Ülkelerde Kadına Yönelik Şiddetin Yaygınlığı

\begin{tabular}{|c|c|c|c|c|c|c|}
\hline \multirow{3}{*}{ Bölge } & \multirow{3}{*}{ Ülke } & \multirow{3}{*}{ Yil } & \multirow{2}{*}{\multicolumn{2}{|c|}{$\begin{array}{l}\text { Kadına Yönelik Fiziksel } \\
\text { Şiddetin Yaygınlığı(\%) } \\
\text { Yakın İlişkide Olunan } \\
\text { Erkekler Tarafından } \\
\end{array}$}} & \multirow{2}{*}{\multicolumn{2}{|c|}{\begin{tabular}{|c|}
$\begin{array}{c}\text { Kadına Yönelik Cinsel Şiddetin } \\
\text { Yaygınlığı(\%) }\end{array}$ \\
$\begin{array}{c}\text { Yakın İlişkide Olunan Erkekler } \\
\text { Tarafından }\end{array}$ \\
\end{tabular}}} \\
\hline & & & & & & \\
\hline & & & $\begin{array}{c}\text { Hayatı } \\
\text { Boyunca }\end{array}$ & Son 12 Ayda & $\begin{array}{c}\text { Hayatı } \\
\text { Boyunca }\end{array}$ & Son 12 Ayda \\
\hline Afrika & Kamerun & 011 & 44,8 & 29,0 & 20,3 & 11,2 \\
\hline Afrika & Misır & 005 & 33,2 & 18,2 & 6,6 & 3,9 \\
\hline Afrika & Kenya & $\begin{array}{l}2008- \\
09\end{array}$ & 37,0 & 31,3 & 17,2 & 13,6 \\
\hline Afrika & Nijerya & 013 & 14,4 & 9,3 & 4,8 & 3,7 \\
\hline Afrika & Tunus & 010 & 20,3 & 7,2 & 14,2 & 9,0 \\
\hline Afrika & Uganda & 011 & 42,7 & 24,9 & 27,3 & 20,9 \\
\hline Asya & Ermenistan & 008 & 8,9 & ... & 3,3 &.. \\
\hline Asya & Azerbaycan & 006 & 12,8 & 9,7 & 2,9 & 2,0 \\
\hline Asya & \begin{tabular}{|l|} 
Çin Halk \\
Cumhuriyeti
\end{tabular} & $999-00$ & 15,4 &.. &.. &.. \\
\hline Asya & Gürcistan & 010 & 4,5 & 1,4 & 1,7 & 0,5 \\
\hline Asya & Hindistan & 005-06 & 35,1 & 21,4 & 10,0 & 7,2 \\
\hline Asya & \begin{tabular}{|l|} 
Japonya \\
\end{tabular} & 010 & 25,9 & .. & 14,1 &.. \\
\hline Asya & Ürdün & 012 & 21,1 & 11,2 & 8,6 & 6,0 \\
\hline Asya & Kırgizistan & 012 & 25,1 & 16,9 & 4,0 & 2,8 \\
\hline Asya & Nepal & 011 & 23,1 & 10,4 & 14,3 & 7,7 \\
\hline Asya & Pakistan & $\begin{array}{l}2012- \\
13 \\
\end{array}$ & 26,8 & 18,0 &.. &.. \\
\hline Asya & Filipinler & 013 & 12,7 & 5,3 & 5,3 & 3,2 \\
\hline Asya & Türkiye & 014 & 36,0 & 8,0 & 12,0 & 5,0 \\
\hline Avrupa & Avusturya & 014 & 12,0 & 2,0 & 6,0 & 1,0 \\
\hline Avrupa & Belçika & 014 & 22,0 & 5,0 & 9,0 & 1,0 \\
\hline Avrupa & Bulgaristan & 014 & 22,0 & 6,0 & 9,0 & 3,0 \\
\hline Avrupa & \begin{tabular}{|l|} 
Çek \\
Cumhuriyeti \\
\end{tabular} & 014 & 19,0 & 4,0 & 7,0 & 1,0 \\
\hline Avrupa & Danimarka & 014 & 29,0 & 3,0 & 11,0 & 1,0 \\
\hline Avrupa & Estonya & 014 & 19,0 & 2,0 & 7,0 & 1,0 \\
\hline Avrupa & Finlandiya & 014 & 27,0 & 4,0 & 11,0 & 1,0 \\
\hline Avrupa & Fransa & 014 & 25,0 & 5,0 & 9,0 & 1,0 \\
\hline Avrupa & Almanya & 014 & 20,0 & 3,0 & 8,0 & 1,0 \\
\hline Avrupa & Yunanistan & 014 & 18,0 & 5,0 & 5,0 & 2,0 \\
\hline Avrupa & İtalya & 014 & 17,0 & 5,0 & 7,0 & 4,0 \\
\hline Avrupa & Lüksemburg & 014 & 21,0 & 3,0 & 9,0 & 1,0 \\
\hline Avrupa & Hollanda & 014 & 22,0 & 4,0 & 11,0 & 2,0 \\
\hline Avrupa & Norveç & 008 & 13,9 &.. & 9,4 & 1,0 \\
\hline Avrupa & Polonya & 014 & 12,0 & 2,0 & 4,0 & 1,0 \\
\hline Avrupa & Romanya & 014 & 23,0 & 6,0 & 5,0 & 2,0 \\
\hline Avrupa & İspanya & 014 & 12,0 & 1,0 & 4,0 & 1,0 \\
\hline
\end{tabular}




\begin{tabular}{|l|l|l|l|l|l|l|} 
Avrupa & İsveç & 014 & 24,0 & 3,0 & 10,0 & 2,0 \\
\hline Avrupa & Ukrayna & 007 & 12,7 & 10,4 & 3,3 & 2,2 \\
\hline Avrupa & $\begin{array}{l}\text { Birleşik } \\
\text { Krallk }\end{array}$ & 014 & 28,0 & 4,0 & 10,0 & 1,0 \\
\hline $\begin{array}{l}\text { Latin Amerika ve } \\
\text { Karayipler }\end{array}$ & Kolombiya & 010 & 37,4 &.. & 9,7 &.. \\
\hline $\begin{array}{l}\text { Latin Amerika ve } \\
\text { Karayipler }\end{array}$ & Ekvator & 011 & 35,0 &.. & 14,5 &.. \\
\hline $\begin{array}{l}\text { Latin Amerika ve } \\
\text { Karayipler }\end{array}$ & Meksika & 011 & 12,3 & 5,4 & 5,9 & 2,5 \\
\hline $\begin{array}{l}\text { Latin Amerika ve } \\
\text { Karayipler }\end{array}$ & Peru & 013 & 35,7 & 11,5 & 8,4 & 3,0 \\
\hline Güney Amerika & Kanada & 009 &.. & 1,3 &.$\cdot$ &.. \\
\hline Güney Amerika & A.B.D. & 011 & 31,5 & 4,0 & 8,8 & 0,8 \\
\hline Okyanusya & Avustralya & 012 & 15,6 &.. & 4,9 &.. \\
\hline Okyanusya & Fiji & $010-11$ & 61,1 & 19,4 & 33,9 & 14,2 \\
\hline Okyanusya & Kiribati & 008 & 60,0 & 32,4 & 46,4 & 33,7 \\
\hline Okyanusya & $\begin{array}{l}\text { Yeni } \\
\text { Zellanda }\end{array}$ & 002 & 30,2 & 5,3 & 14,1 & 2,1 \\
\hline
\end{tabular}

Kaynak: UNSTATS (2015), The World's Women 2015: Trends and Statistics, https://unstats.un.org/unsd/gender/chapter6/chapter6.html (Erişim Tarihi:14.03.2018) 
Tablo 2. Seçilmiş Ülkelerde Kadınların Iş̧gücüne Katılım Oranı (15-64 yaş)

\begin{tabular}{|c|c|c|c|c|c|}
\hline Siralama & Ülke & 2016 & Siralama & Ülke & 2016 \\
\hline 1 & Katar & 99,3 & 41 & Hirvatistan & 60,9 \\
\hline 2 & San Marino & 86,5 & 42 & Yunanistan & 60,5 \\
\hline 3 & İzlanda & 86,3 & 43 & Ukrayna & 60,4 \\
\hline 4 & İsveç & 80,2 & 44 & Paraguay & 60,1 \\
\hline 5 & İsviçre & 79,5 & 45 & Tayvan, Çin & 59,6 \\
\hline 6 & Danimarka & 77,2 & 46 & Namibya & 59 \\
\hline 7 & Norveç & 75,9 & 47 & Brezilya & 58,9 \\
\hline 8 & Barbados & 75,7 & 48 & Kuveyt & 58,6 \\
\hline 9 & Hollanda & 75 & 49 & Ekvador & 58,5 \\
\hline 10 & Yeni Zelanda & 74,9 & 50 & Kore Cumh. & 58,4 \\
\hline 11 & Kanada & 74,4 & 51 & Sirbistan & 58,1 \\
\hline 12 & Finlandiya & 74,1 & 52 & Mali & 58 \\
\hline 13 & Letonya & 74 & 53 & Karadağ & 56,6 \\
\hline 14 & Litvanya & 73,9 & 54 & Panama & 56,6 \\
\hline 15 & Almanya & 73,6 & 55 & Şili & 56,3 \\
\hline 16 & Estonya & 73,2 & 56 & Moğolistan & 56,2 \\
\hline 17 & Birleşik Krallık & 72,2 & 57 & Romanya & 56,2 \\
\hline 18 & Avusturya & 71,7 & 58 & Malta & 55,6 \\
\hline 19 & Avustralya & 71,6 & 59 & İtalya & 55,2 \\
\hline 20 & Peru & 71,4 & 60 & Malezya & 54,3 \\
\hline 21 & Portekiz & 70,5 & 61 & Belize & 53,9 \\
\hline 22 & İspanya & 69,2 & 62 & Endonezya & 53 \\
\hline 23 & Slovenya & 68,6 & 63 & Güney Afrika & 52,3 \\
\hline 24 & Kibris & 68,5 & 64 & Kırgızistan & 51,8 \\
\hline 25 & Singapur & 68,5 & 65 & Makedonya & 50,8 \\
\hline 26 & Japonya & 68,1 & 66 & El Salvador & 50,6 \\
\hline 27 & Uruguay & 67,9 & 67 & Fildiși Sahili & 50,5 \\
\hline 28 & Çek Cumhuriyeti & 67,6 & 68 & Kosta Rika & 50,1 \\
\hline 29 & Fransa & 67,6 & 69 & Filipinler & 49,8 \\
\hline 30 & Amerika Birleşik Devletleri & 67,3 & 70 & Meksika & 47 \\
\hline 31 & Peru & 66,5 & 71 & Moldova & 45,7 \\
\hline 32 & Slovakya & 65,4 & 72 & Guatemala & 42,4 \\
\hline 33 & Hong Kong, Çin & 64,7 & 73 & Bosna Hersek & 40,9 \\
\hline 34 & Lüksemburg & 64,7 & 74 & Türkiye & 36,2 \\
\hline 35 & Bulgaristan & 64,6 & 75 & Bangladeș & 34,7 \\
\hline 36 & Jamaika & 63,8 & 76 & Misir & 24,1 \\
\hline 37 & İrlanda & 63,7 & 77 & Suudi Arabistan & 23,3 \\
\hline 38 & Macaristan & 63,5 & 78 & Kosova & 18,6 \\
\hline 39 & Belçika & 62,9 & 79 & İran & 17,5 \\
\hline 40 & Polonya & 62 & & & \\
\hline
\end{tabular}

Kaynak: http://www.ilo.org/ilostat/ (Erişim Tarihi: 